\title{
FACTORS OF RISK AND PROTECTION/RESILIENCE IN ADOLESCENT SCHOLAR BULLYING Longitudinal analysis
}

\section{FACTORES DE RIESGO Y PROTECCIÓN/RESILIENCIA EN EL ACOSO ESCOLAR ADOLESCENTE}

Análisis longitudinal

\author{
Teodoro Hernández de Frutos theo@unavarra.es \\ Navarra Public University. Pamplona. Spain.
}

NuRIA DEL OLmo VICÉN nolmov@unizar.es

Universidad de Zaragoza. Spain.

\begin{abstract}
Theories of risk, protection and resilience have gained widespread acceptance in recent years, as the university community, to a large extent, consider that they offer a satisfactory explanation as to why some adolescents fail to survive in a hostile environment while others cope adequately, almost as if they were immunized against the difficulties they encounter in the course of their lives. Applying these theories to adolescent harassment could explain why certain youth fall victim to it and others do not, despite sharing the same life variables: age, sex, school structure, family structure, residential area, mass media and so on. This longitudinal analysis examines the risks and resilience associated with the social environment, using Bronfenbrenner's version, taking into account that resilience is not necessarily due to individual personality conditioning or other significant factors, as some theories hold. Rather, it argues that environmental factors may also be responsible for increasing or reducing its effects. Given that some experts use this concept in a manner that leads to confusion, understanding adolescent bullying to be aggressive behavior on an individual level, it is necessary to highlight that it is understood here to be a multidimensional concept. It is a single variable which includes individual aggression, collective aggression, individual and collective victimization. This will avoid the misunderstanding arising from a holistic and undifferentiated use of the term. It also takes into account that the aggressor as well as the victim is also exposed, although to a lesser degree, to risks, protection and resilience.
\end{abstract}

\section{KEYWORDS}

Adscriptive Factors; Cultural Factors; Heterosexuality; Institutional Factors; Protection; Race and Ethnic Groups; Resiliency; Risk.

\section{ResUmen}

Las teorias del riesgo, protección/resiliencia han surgido con fuerza en los últimos años porque explican satisfactoriamente, en opinión de una por parte significativa de la comunidad universitaria, porque algunos adolescentes se hunden en un medio ambiente hostil, mientras que otros sobreviven sin que parezca que les afecte, como si estuvieran inmunizados contra las adversidades que se han ido encontrando a lo largo de su vida. Estas teorías aplicadas al acoso adolescente podría explicar porque algunos jóvenes lo padecen y otros no, a pesar de compartir la misma atmósfera vital (edad, género, escuela, barrio, medios de comunicación). El presente meta análisis indaga sobre los riesgos y resiliencias procedentes del medio ambiente social en la 
versión de Bronfenbrenner tomando en cuenta que las resiliencias no necesariamente tienen que proceder de aspectos individuales debidos a la personalidad o a los otros significantes, como enfatizan algunas teorías, sino que pueden ser también factores ambientales los que ejerzan ese papel incrementando o reduciendo los efectos. Dado que en una parte de la literatura especializada se utiliza el concepto de manera confusa identificando acoso escolar solo con un comportamiento agresivo individual, es necesario apuntar que aquí se utiliza como un concepto mutidimensional, es decir, como una única variable que incluye la agresión individual, la agresión colectiva, la victimización individual y la victimización colectiva. De esta forma se evita el malentendido de un uso holístico y omnicomprensivo no siempre diferenciado, lo que puede provocar confusión. Tomando en cuenta además que tanto el que ejerce como el que lo padece, aunque en diferente grado, se enfrentan a riesgos, protección y resiliencia.

\section{Palabras Clave}

Factores Adscriptivos; Factores Culturales; Factores Institucionales; Hetrosexualidad; Protección; Razal etnia; Resiliencia; Riesgo.

\section{INTRODUCTION}

According to the bioecological model formulated by Bronfenbrenner and Ceci 1994; Bronfrenbrenner (2005) the effects of the interaction of particular organisms, known as proximity processes vary depending on environmental characteristics. This model predicts ecome involved in violent crime, proximity processes and other environmental influences will have a greater impact on the development of youth in unfavorable surroundings than on youth in unfavourable surroundings. Human development results from a continuous interaction between an active human being and its immediate surroundings, which are also constantly in a process of change. Moreover, this process is influenced by the relations established between these surroundings and the wider context in which these surroundings are situated, which in turn is subject to change. Thus, development is a process that derives from personal (including genetic) and environmental characteristics, both immediate and remote, and within a continuum of changes occurring within it over time. Genetic potential is expected to play an active role for youth from disadvantaged backgrounds to increase the potential of the genotype correlations with the environment. Bronfenbrenner (2005) calls this set of serial structures ecological environment, each of which fits into the next, possessing the particular feature of being able to influence each other. He also proposes that each one of the humans work and live in a particular and individual system that is linked through social and environmental interactions with particular systems of other human beings.

Moreover, risk is defined as the conditions that prevent a consistent pattern of positive behavior and wellbeing. The risk perspective is compatible with an ecological framework because both perspectives include variables that occur across the domains of the individual, family, school, adolescence and the environment (Peters \& Ehrenberg, 2008). Resilience is a concept that originated in physics. Since it was transplanted into the field of development science and research on social behavior a generation ago, it has 
inspired the research of the main protective factors, opportunities, and experiences that enable young people to resist stress and even thrive in adversity. In recent times, it has become the basis for programs, policies and practices in public healthcare that aims to use the dual strategy of reducing risk while enhancing protective factors that keep young people on a path of healthy development (Resnick and Taliaferro, 2011). Resilience is defined primarily in terms of "presence of protective factors (personal, social, family and institutional)" which allows people to withstand the stresses of life. The resistance of an individual at any time is calculated by the relationship between the presence of protective factors and the presence of dangerous circumstances. The resilience of an individual at any given moment is calculated by the relationship between the presence of protective factors and the presence of dangerous circumstances.

Adolescents that have experienced bullying or have caused bullying presented emotional behavioral problems in their present and future lives are more likely to have low academic performance, often repeating the school year, expelled from school, developing behavioral problems that intensify in adulthood and are less active in getting involved in social activities outside of school (Sing \& Ghandour, 2012). Awareness of the effects of social factors or variables that affect bullying is essential when considering preventive measures to be taken to alleviate the problem for the perpetrator and the victim. Bowles et al (2009) argue that the broader socio-environmental context, including school, neighbourhood and family, can also influence the risk of adolescents of being involved in bullying at the young age of five-seven. In terms of teenagers and young adults, we recommend including two other contextual variables in their possible interaction in the study possibly in the environment in which adolescents are involved

\section{ADSCRIPTIVE RISK AND PROTECTION/RESILIENCE FACTORS}

Sexual identity is a great risk for adolescents in school bullying as in this period, they begin to develop a sense of identity by affiliating with others who are similar to themselves and for many youth, this similarity could be based on sex or genre. Adolescents face a variety of challenges in their transition to adulthood; lesbian, gay, and bisexual adolescents face these typical challenges as well as additional challenges that are related to the social stigma of their sexual orientation. Many lesbian, gay, bisexual, and transgender (LGBT) youth are more likely than their heterosexual peers to experience difficulties such as bullying in their lives and school environments. Negative attitudes towards LGBT youth increased their risk of experiencing violence, compared with other students. For some adolescents this stigma may induce psychosocial stress, leading to an increase in behavior that put their health at risk. Violence can include behavior such as bullying, teasing, harassment, physical assault, and suicide-related behaviors. Adolescents who identify themselves as LGBT are two to three times more likely to consider or attempt suicide than heterosexual youth. LGBT youth have also reported higher rates of mental health and substance use problems than heterosexual youth, and higher rates of these 
problems have been associated with higher rates of suicidal ideation and attempts in adolescents. This is of particular concern because LGBT youth have consistently reported harassment, bullying, and other forms of victimization at significantly higher rates than heterosexual youth. The question is so important that President Obama and his wife held a White House Conference on Bullying Prevention. As part of this conference, a series of white papers were released including one specifically on bullying and the LGBT community. In 2011, the U.S. Department of Education hosted its first-ever LGBT Youth Summit highlighting the administration's commitment to ensuring equal access to education for LGBT students.

Olsen et al., (2011) summarizes results from the Youth Risk Behavior Surveillance System conducted during 2001-2009 in seven states and six large urban school districts that included questions on sexual identity, sex of sexual contacts or both of these variables. The surveys were conducted among large population-based samples of public school students in grades 9-12. Across the nine sites that assessed sexual identity, the prevalence among gay or lesbian students was higher than the prevalence among heterosexual students for a median of $63.8 \%$ of all the risk behaviors measured, and the prevalence among bisexual students was higher than the prevalence among heterosexual students for a median of $76.0 \%$ of all the risk behaviors measured. In addition, the prevalence among gay or lesbian students was more likely to be higher than (rather than equal to or lower than) the prevalence among heterosexual students for behaviors in seven of the 10 risk behavior categories (behaviors that contribute to violence, behaviors related to attempted suicide, tobacco use, alcohol use, other drug use, sexual behaviors, and weight management). Similarly, the prevalence among bisexual students was more likely to be higher than the prevalence among heterosexual students for behaviors in eight of the 10 risk behavior categories. Across the 12 sites that assessed sex of sexual contacts, the prevalence among students who had sexual contact with both sexes was higher than the prevalence among students who only had sexual contact with the opposite sex for a median of $71.1 \%$ of all the risk behaviors measured, and the prevalence among students who only had sexual contact with the same sex was higher than the prevalence among students who only had sexual contact with the opposite sex for a median of $29.7 \%$ of all the risk behaviors measured. They found that LGB students were much more likely to have been in a physical fight on school property than heterosexual students across most of the YRBS sites that asked those questions - median of $19.1 \%$ for gay and lesbian students and median of $15.7 \%$ for bisexual students compared to median of $10.5 \%$ among heterosexual students.

Robinson and Espeleage (2011) upon an analytic data set containing anonymous survey responses in 2008-2009 from a total of 13,213 students ( $n=3,826$ middle school; $n=9,387$ high school) in 30 schools in Dane County, Wisconsin. The survey included 117 items on a range of topics including sexual identity, suicide, sexual behavior, drug usage, bullying, and victimization. The Dane County Youth Assessment (DCYA) is a survey administered across all schools in the county as a collaborative project among the schools and several community organizations. The county represented geographically diverse areas 
ranging from small working farms to a large city. The survey assessed a wide range of physical and mental health indicators, as well as various attitudes and social behaviors. Students completed these anonymous surveys independently during proctored sessions while in school. A waiver of active consent was employed, and child written assent was used. Surveys were completed by all 7th- through 12th-grade students, and the response rate was very high, ranging from $90 \%$ to $95 \%$ across the 30 schools. The DCYA data set contains a total of 17,366 student responses. This study finds that, compared with straight-identified youth, youth who identify as lesbian, gay, bisexual, transgender, or questioning are at greater risk of suicidal thoughts, suicide attempts, victimization by peers, and elevated levels of unexcused absences from school. Results disaggregated by LGBTQ subgroups reveal heterogeneity within the broad LGBTQ group, with bisexual youth appearing to be particularly at risk. Also, although the risk gaps in school belongingness and unexcused absences are significant in high school, they find that these gaps are significantly greater in middle school, suggesting heightened early risk for LGBTQ-identified students.

Agree Poteat et al. (2011), many adolescents experience peer victimization, which often can be homophobic. Applying the minority stress model with attention to intersecting social identities, this study tested the effects of general and homophobic victimization on several educational outcomes through suicide and school belonging among 15,923 adolescents in Grades 7 through 12 on account of their sexual orientation and race/ ethnicity. Parent support also was tested as a moderator of these effects. Homophobic victimization had different effects on suicide across groups, indicating the importance of considering individuals' multiple social identities. However, homophobic victimization had universal negative effects on school belonging for all groups. Nearly all indirect effects of general and homophobic victimization on reported grades, truancy, and importance of graduating were significant through suicide and school belonging across groups. Parent support was most consistent in moderating the effects of general and homophobic victimization on suicide for heterosexual White and racial/ethnic minority youth. In nearly all cases, it did not moderate the effects of general or homophobic victimization for lesbian, gay, bisexual, transgender, and questioning youth. Furthermore, in most cases, parent support did not moderate the effects of general or homophobic victimization on school belonging. Findings underscore the need for counseling psychologists to work with parents of all youth on ways to provide support to those who experience homophobic victimization. Furthermore, they highlight the need for counseling psychologists to be involved as social justice advocates in the passage and implementation of school policies that address homophobic bullying and other forms of bias-based bullying and harassment.

In one school-based survey (Kosciw J. et al., 2011), completed a survey about LGBT experiences in school, including hearing biased remarks; feeling safe, being harassed, and feeling comfortable at school; and academic experiences, attitudes about school, and involvement in school. Youth were eligible to participate in the survey if they were at least 13 years of age, in the United States during the 2010-11 school year, and identified as lesbian, gay, bisexual, or a sexual orientation other than heterosexual or identified as 
transgender or as having a gender identity other than male, female, or transgender. The final sample consisted of a total of 8,584 students between the ages of 13 and 20. Students came from all 50 states and the District of Columbia and from 3,224 unique school districts. About two thirds of the sample $(67.9 \%)$ was White, about half $(49.6 \%)$ was female, and over half identified as gay or lesbian (61.3\%). Sexual orientation and gender expression were the most common reasons LGBT students were harassed or assaulted at school. More than $80 \%$ of students reported being verbally harassed at school because of their sexual orientation; nearly two thirds were verbally harassed because of their gender expression. Four in ten students reported being physically harassed at school because of their sexual orientation. One in five students reported being physically assaulted (e.g. punched, kicked, or injured with a weapon) at school in the past year because of their sexual orientation, gender expression, or gender. Relational aggression like being deliberately excluded by peers or mean rumors being spread was reported by the vast majority of students. More than half of the students reported experiencing some form of electronic harassment ("cyberbullying") in the past. Nearly three quarters of LGBT students heard homophobic or sexist remarks often or frequently at school. More than eight in ten students heard the word "gay" used in a negative way often or frequently at school. More than half of students heard homophobic remarks from school personnel. Less than a fifth of students reported that school personnel frequently intervened when hearing homophobic remarks or negative remarks about gender expression.

Himmelstein and Bruckner (2011), found that non-heterosexual adolescents often face discrimination. At home, some non-heterosexual adolescents experience verbal and physical abuse; $26 \%$ of non-heterosexual children leave their families because of conflicts over sexual orientation, and many become homeless. Thirty percent suffer family violence after "coming out". Harassment by peers is also common. It is not surprising that nonheterosexual adolescents experience high rates of depression and suicide. In addition, they are more likely than other adolescents to engage in high-risk sexual and substance-use behavior, to carry weapons (often as a precaution against assault), and to engage in petty survival crimes because of homelessness. These activities place non-heterosexual adolescents at risk for school and criminal-justice sanctions. Non-heterosexual youth also are more likely than their peers to be referred to courts by their families through PINS (Person in Need of Supervision) or CHINS (Child in Need of Supervision) petitions. In addition, consensual same-sex sexual acts more often trigger punishments than equivalent oppositesex behaviors. Indeed, until the Supreme Court's 2003 ruling in Lawrence et al vs Texas, states could legally prosecute same sex couples for consensual sexual acts. Anecdotal reports have suggested that non-heterosexual girls may be particularly overrepresented in the juvenile-justice system. Scholars have suggested that the overrepresentation of non-heterosexual girls may relate to the historical role of the juvenile-justice system in policing girls' sexuality, as well as a heightened juvenile-justice system and media opprobrium directed at girls with aggressive or masculine gender presentations.

O'Maley et al. (2014) argued upon two large population data set based on Youth Risk Survey from 10 states and 10 large urban district in USA, sexual minority students 
are at greater risk for school violence and bullying than heterosexual students. In one district data set, gay male students and bisexual male students were more likely than heterosexual male students to have experienced all five school violence and bullying behaviors. Compared with heterosexual male students, gay students were about three times more likely to have not gone to school because of safety concerns and bisexual male students were about three times more likely to have carried a weapon and been bullied on school property. Anyway, in the state data set, lesbian and bisexual female students were more likely than heterosexual female students to have experienced all five school violence and bullying behaviors, although the increased risks were generally not as high among bisexual female students as they were for lesbian students. Compared with heterosexual female students, lesbian students were about three times more likely to have been in a physical fight on school property and not gone to school because of safety concerns, about four times more likely to have been threatened or injured with a weapon on school property, and about six times more likely to have carried a weapon on school property. In the district data set, lesbian and bisexual female students were more likely than heterosexual female students to have been in a physical fight on school property, been threatened or injured with a weapon on school property, carried a weapon on school property, and not gone to school because of safety concerns. Bisexual female students were also more likely to have been bullied at school.

Another important variable is childhood's obesity. Overweight and obese schoolaged children are more likely to be the victims and perpetrators of bullying behaviors than their normal-weight peers. These tendencies may hinder the short- and long-term social and psychological development of overweight and obese youth. The obesity rates have risen dramatically in many countries in the past few decades (Institute of Medicine, 2011). Some research suggests a higher prevalence of obesity among lesbians than among heterosexual women. However, almost no research has examined weight-related patterns among LGBT youth. Despite significant attention to the medical impacts of obesity, often ignored are the negative outcomes that obese children and adults experience as a result of stigma, bias, and discrimination. Obese individuals are frequently stigmatized because of their weight in many domains of daily life. For overweight and obese youth, weight stigmatization translates into pervasive victimization, teasing, and bullying. Multiple adverse outcomes are associated with exposure to weight stigmatization bullying, including depression, anxiety, low self-esteem, body dissatisfaction, suicidal ideation, poor academic performance, lower physical activity, maladaptive eating behaviors, and avoidance of health care (Puhl and King, 2013).

Jansen et al. (2004) found that with the exception of 15- to 16 year-old boys, relationships were observed between Body Mass Index (BMI) category and peer victimization, such that overweight and obese youth were at greater relative odds of being victims of aggression than normal-weight youth. Strong and significant associations were seen for relational (e.g. withdrawing friendship or spreading rumors or lies) and overt (e.g. name-calling or teasing or hitting, kicking, or pushing) victimization but not for sexual harassment. Independent of gender, there were no associations between BMI category 
and bully-perpetrating in 11- to 14-year-olds. However, there were relationships between BMl category and bully-perpetrating in 15- to 16-year-old boys and girls such that the overweight and obese 15- to 16-year-olds were more likely to perpetrate bullying than their normal-weight classmates. Associations were seen for relational (boys only) and overt (both genders) forms of bully-perpetrating but not for sexual harassment. Austin et al., (2009) drawing on data from the 1998-2005 waves of the Growing Up Today Study $(n=13,785$, ages 12-23), found sexual orientation group disparities in BMl are evident early in adolescence. We found a fairly consistent relationship between minority sexual orientation and elevated BMI in females, particularly at the older ages in the observed period. In contrast, in males we identified a significant age-by-sexual-orientation interaction. Gains in BMI from early through late adolescence in heterosexual males were notably higher than that in sexual orientation minority males. We also found a significant gender-by-sexual-orientation interaction in attained weight status by young adulthood in which sexual-minority females but not sexual-minority males were at elevated risk of overweight. The long-term health consequences of excess weight are well-documented (2) and over time are likely to exact a high toll on communities with elevated rates. Sexual orientation group disparities found among females in the GUTS cohort are as large as those observed in other national studies comparing BMI across racial/ethnic and socioeconomic groups.

Farhat et al. (2010) conclude in a study aiming to examine the association of overweight and obesity with health-risk behaviors among U.S. youth in a nationally representative sample of students aged 11-17 years ( $N=7825)$ who participated in the 20052006 Health Behaviors in School-Aged Children survey that exist significant gender and age differences in the relationship of overweight/obesity with risk behaviors. Overweight and obesity were significantly associated with substance use among girls only: Frequent smoking and drinking were associated with overweight and obesity among younger girls, whereas these behaviors were associated with obesity among older girls. Frequent smoking and cannabis use were associated with overweight among younger girls only. Relationships between violent behavior and overweight/obesity were mainly observed among boys: Younger obese boys were more likely to be victims of bullying, whereas older obese boys were more likely to carry weapons compared to boys of normal weight.

\section{INSTITUTIONAL RISK AND PROTECTION/RELIANCE FACTORS}

Risk in the family has been defined as the conditions which prevent a constant pattern of positive behavior and wellbeing existing in the home. Adolescents' family environment and interactions can affect bullying behavior through multiple mechanisms. Family violence shapes bullying behavior through the modeling of aggressive behavior and the establishment of pro aggression norms. For example, both exposure to interparental conflict and adolescent physical punishment have been positively associated with bullying perpetration. Parental monitoring problems affect aggression through adolescents' unsu- 
pervised time and affiliation with deviant peers. Bullies experience more lax or inconsistent parental monitoring than non-bullies, and victims experience more intrusive parental involvement than non-victims. Other features of family relationships, including low parental warmth, low family cohesion, low involvement with parents, and single parent family structure have also been positively associated with bullying involvement (Springgs et al., 2007). The types of risks that parents in fragile families are exposed to - drugs, alcohol, prison sentences - are frequently considerable and may be associated with low levels of parental involvement with the children. Parents with high levels of passive risk may reject their implication in the socialization of their children because their own problems may prevent them from doing so. It has also been suggested that prolonged absences of the parents during the first year of the child's life may later have a negative effect on their commitment with the child. The first year of the child's life is crucial in the transition to parenthood, since parents may not be able to compensate later on in the child's life for the negative effects of this period of potential risk. Failure to bond at this early stage may result in a poor mother child relationship.

The high levels of risk experienced add more stress to the child's upbringing, and tend to correlate negatively with the father's commitment (Bronte-Tinkew, et al., 2010). It has been demonstrated that women choose relationships that they consider potentially favorable for their future families, as they consider that some partners would not be capable of offering security to their offspring. Qualitative studies of single parents with low incomes have demonstrated that mothers choose their children's father based on the perception they have of his future relationship with the children, and the outcome will only be successful if the father does not have problems of his own which prevent him from taking care of his children. Relationships among members of a family can be of high risk or of protection/ resilience depending on the number of siblings, whether they be brothers or sisters. The family It establishes what conduct is socially reprehensible; it innately regulates basic behavior with regard to life and to others (Peterson and Bush, 2013).

Fragile family has become increasingly prevalent in recent years. The effect on the family of prolonged and unforeseen economic difficulties, caused by a conjunctural crisis which affects a country's economy, a region or a locality. This has been denominated as "the family stress or the tension model. Three examples are the influence on the family of industrial reconversion, the fall in agricultural prices and 2007-2009 economic recessions (Menasco, 2012). When the family has to face problems of low salaries, loss of employment or economic ruin, an unpleasant domestic atmosphere is consequently produced. This may manifest itself in children's behavior, since they are subjected to unfamiliar and stressful situations. In the face of such adversities, the family may find itself unable to take responsibility for basic shopping, adequate food or the health care one or more of them requires. Economic pressures increase emotional stress between spouses over time, which in turn causes a substantial increase in matrimonial conflict, often followed by a proposal for separation or divorce. Children's behavior, in turn, is a function of the coping mechanism they have developed to deal with caregiver's emotional distress. Youths of whom both parents are unemployed are associated with children's bullying 
behavior through its relation with low educational level, single parenthood, and disadvantaged school neighborhoods (Jansen, 2012). Couples with weaker social skill, are at greater risk of conflict escalating to the point of violence, especially during times of stress. Parental stress is linked to more punitive and less emotionally supportive parenting and to low-income children's internalizing and externalizing problems and tends to co-occur with other aspects of well-being (Brophy- Herb et al., 2013). There is also evidence that fathers with high levels of risk also experience more parenting stress, which tends to be negatively related to father engagement with children. Fathers may have a difficult time recovering from the negative effects of their risk as the child grows older because they have not been able to form early bonds with the child or because their relationship with the mother was poor (Waldfogel et al., 2010). In general, adolescent who live with two parents are households are less likely to have ever-used cigarettes, alcohol, and marijuana while males who live in two-parent households are less likely to have used cigarettes and marijuana less likely to engage in delinquent acts, are less likely to fight, and more likely to do well in school.

The school is, in all probability, the environmental variable that carries the highest risk and resilience in the process of adolescent bullying. In the majority of Western countries schooling is compulsory for youths up to a certain age. Attending school is therefore obligatory until youths have fulfilled the educational objectives which society has designed via its laws. National education systems regulate school socialization establishing different rights and obligations for students. This allows schools, within certain limits, to design the disciplinary codes known as the school regulations. A school which functions well with a predisposition towards learning and standing out among others has been identified as a factor which discourages violence. In contrast, academic failure, idleness and the imposition of rules have been explanatory factors of aggressiveness. School climate refers to the quality and character of school life. School climate is based on patterns of people's experiences of school life and reflects norms, goals, values, interpersonal relationships, teaching and learning practices, and organizational structures. A sustainable, positive school climate fosters youth development and learning necessary for a productive, contributive, and satisfying life in a democratic society. This climate includes norms, values, and expectations that support people feeling socially, emotionally, and physically safe (Cohen et al., 2009) and affect the satisfaction, efficacy, and commitment of teachers and thus the academic engagement and achievement of students.

Atmosphere in the school may affect the levels of violence within schools, because both the formal and informal atmosphere-hidden curriculum- perceived by adolescents in their schools fundamentally influences their behavior. Contentment with school is one of the principal aspects of pupils' quality of life; it affects psychological wellbeing, involvement at school, truancy rates, premature school leaving and behavioral problems (Raskauskasa J. et al., 2010). School violence affects a high percentage of the visible and invisible norms of the groups which exist inside the school. Any youth who departs from the formal or informal generalised consensus will be rejected; thus, the groups' behavior 
is fundamental for the young member and constitutes a basic protective umbrella to ensure his or her physical and psychological safety. However, as secondary school coincides with a period of far-reaching physiological-hormonal changes, various transitions take place which shatter the existing climate of group norms. Firstly, group leadership and the status of domination must be restated or reoriented, depending on pupils' age. Secondly, secondary school is a transition period which is opposed to stable norms. This stage of life generates tension and frustration which may lead to an increase in rebellious attitudes.

The nature of school life is naturally affected by the district and community (local, state, and national) that it operates within elementary school in affluent neighborhoods get better teacher than those in poor neighborhoods and that this affects how much students learn. Not yet considered, however, are compositional differences due to the fact that some high schools serve a larger number of students with a history of disruptive behavior problem? For example, the prevalence of behavioral problems is higher in underprivileged areas, and the fact that teachers have a greater tendency to negatively perceive the social climate in schools located in these areas has shown that students from underprivileged backgrounds are often evaluated more negatively and disciplined more frequently by teachers. This phenomenon of contamination is well known but is not necessarily taken into account in studies of school climate and classroom behavior problems. Moreover, exposure to violence in a larger school environment may reduce the quality of teaching, disrupt classroom discipline, and limit teachers' availability to students before and after the school day (LeBlanc et al., 2007).

The involvement of parents in the education environment can make a difference in how children behave, maintaining a presence through activities such as participation on the school council and in the appropriate elections held to elect their representatives, by far the most important group activity in this regard. According to the Spanish Institute for Assessment and Quality of the Education System (2006), in one of the few reports that includes this type of information, $67 \%$ (21\% on an active basis) of parents were involved in school associations in primary education and $58 \%$ ( $15 \%$ on an active basis) in secondary education in Spain, suggesting that parental participation is most frequent in the election of representatives to the school council when their children were younger than 12 years old. In terms of individual activity, another form of parental involvement entails participation in the different activities carried out in schools throughout the year, and in monitoring the performance of children through direct communication with the appropriate teacher, tutor or head. The participation of parents of students in the final year of compulsory education was $74 \%$ in the teaching process, which involves attending meetings and collaboration in the classroom during school hours; $51 \%$ in cultural activities such as sports, music and theatre, performed outside and within school hours; $42 \%$ in extracurricular activities such as trips, care of the school library and school parties; and $44 \%$ in group activities, such as fundraising and maintenance of the school. These data demonstrate the existence of increased awareness by parents about what is happening 
in school for children that have not yet reached adolescence, a stage when students are under less supervision by parents at all levels.

For many years, schools in Spain have maintained a passive stance toward teen bullying, with the understanding that the role of teachers was to teach, rather than participate in mediation in these cases, with the same applying to school management and support staff. However, there is now a realization that this was not exactly the case, after the unfortunate fate of a Basque youth named Jokin who committed suicide in Hondarribia after suffering a campaign of bullying from certain classmates and the failure of certain teachers to intervene when they would have been aware of what was going on. This marked the beginning of the organisation of awareness campaigns to educate the public, to train teachers and to systematically report any case that became known. Bullying was no longer something which took place behind closed doors and was now a public matter which seriously affected schools, and more specifically, school management. This led to the introduction of certain laws and punishments meant to serve as an example to others. Many schools have gone from being a serious risk variable context to one representing protection and resilience.

The factors of protection and resilience in a community is composed of its social capital, its physical infrastructure and its patterns of interdependence. A community's resilience is its social capital, physical infrastructure and its culturally embedded patterns of interdependence that confer it the ability to recover from drastic change, sustain its adaptability and support new growth that incorporates the lessons that have been learned during a period of crisis. Communities are key when it comes to bullying at school as they represent large groups of individuals that interact to achieve individual and collective results, varying in their structure, function and performance over time. Communities, like systems, are open and dynamic and must change and evolve to achieve their results and to remain viable for their citizens. Ungar (2011) found evidence to support that communities are spaces for prevention, which involves a number of locations in a physical and geographical sense including limits and boundaries. These limits have associated deficits and resources involving a certain level of organization of individuals and families that captures the range of the most important connection between individuals and their physical and social environment, including relationships, connections and networks. The aspects of the capacity of the social organization community are focused on the development of informal social networks to improve the lives of the community and to enable groups to achieve desired results, including community resilience. This involves identifying and selecting community norms, beliefs and expectations that apply to specific topics (i.e. prevention of youth violence, improvement of neighborhood safety, or the promotion of school success), which is a primary consideration in promoting change. Within this context, community resilience is the ability of communities to cope with and adapt to the context of challenge and adversity in ways that promote the successful achievement of results. This definition of community resilience is in line with the widely accepted definition of resilience articulated by several authors in the sense of being "a dynamic process encompassing positive adaptation within the context of significant adversity". Communities may face many difficulties and challenges that require collective attention and management at any given time. 


\section{CULTURAL RISK AND PROTECTION/RELIANCE FACTORS}

One of the most accepted explanation used about the effects of mass-media is the risk and resilience theory which relates, on the one hand, the risks to which young people are subjected, amongst them exposure to the mass media, and their capacity to remain immune to them. Authors such as Boxer et al. (2008) highlights the cumulative risk of violent media together with exposure to violence in the community, in the family, in the school and peer groups, academic difficulties, psychopathic tendencies or callousnessunemotionality and psychopathology or related emotional problems. Exposure to entertainment media violence is a risk factor for aggressive behavior, but the presence of this single risk factor is not sufficient to cause children to pick up guns and begin shooting. However, with each additional risk factor children have for aggressive behavior, the risk of that child acting violently compounds (Gentile and Sesma, 2003). Though simple in premise, the strength in such an approach lies in its acknowledgment that a true challenge to the developmental system comes from the interaction of multiple risk factors, and that this cumulative risk process is greater than any one single-risk factor in derailing development. Resilience is an interactive concept that refers to a relative resistance to environmental risk experiences, or the overcoming of stress or adversity (Rutter, 2006). Current thinking regarding resilience assumes that successful outcomes despite stress exposure arise out of dynamic interactions between the child and the environment. In some circumstances, the experience of stress or adversity sometimes strengthens resistance to later stress a so called "steeling" effect. Also there are protective factor, referring to something that modifies the effects of risk in a positive direction, something that is helpful or beneficial. Resilience occurs as a result of multiple protective factors - genetic, interpersonal, contextual, and societal - that impinge on the child as well as interact with the child to counteract the negative effects of stress. The approach to understanding the multicausality of behavior state that the premise behind a cumulative risk model is simple: the more risks encountered by a child, the greater the likelihood of problematic functioning.

Race most commonly refers to physical qualities, such as skin color, and assumes some shared ancestry while ethnicity usually includes cultural beliefs and practices. Bullying based on these factors tends to happen most often among students in different racial and ethnic groups. However, ethnic bullying within the same racial groups has been noted. The racial and ethnic make-up of the particular schools students attend can contribute to episode of bullying. Students of minority races or ethnicities within school buildings are more likely than majority students to experience bullying, especially the type that is based on their race or ethnicity. Preference for one's own group is a normal part of development, but hostility toward those in other groups varies among children. A child's ability to consider another's views or feelings, how much competition or conflict a student experiences directly or believes exists between groups at school or in the community, and prejudicial beliefs (such as an unreasonable fear of foreigners) expres- 
sed by important people in a child's environment all factor in to the likelihood of he or she bullying others. The experience of immigration or being the children of immigration parents ensure that development of ethnic identity is made more complex by the process of acculturation and intergenerational conflict. Youth are likely to experience a great deal of tension as a result of trying to balance their family's traditions and those of their new host culture (McKenney et al., 2006)

Differences in social rules, language, dress, and religious practices may contribute to bullies' views of victims as strange or weak. These differences can lead to students being less accepted by their peers, having fewer friends from other cultures, and feeling isolated or lonely. Pain from the experience of immigration, and from being bullied, could lead students to believe that there is a need to protect oneself or one's group rather than put up with being bullied-sometimes resulting in a decision to bully others. Tension about race, ethnicity, and immigration can result in violence and harassment in school, making it an unsafe learning environment. The number of children seeking help for racist bullying increased sharply last year, as campaigners warn that the heated public debate about immigration is souring race relations in the classroom. More than 1,400 children and young people contacted ChildLine in England for counseling about racist bullying in 2013, up 69 per cent on the previous 12 months. Islamophobia is a particular issue in schools, according to the charity, with young Muslims reporting that they are being called "terrorists" and "bombers" by classmates. Children who have poor English or a strong accent are often called "freshies" -an abusive term that highlights their struggle to fit in. The rise in children needing help for xenophobic bullying coincides with rising political hostility to immigration - especially in the lead-up to this month's lifting of restrictions on Rumanians and Bulgarians entering the United Kingdom. In 2011, just 802 children approached the charity seeking help for racist bullying. Overall, the number of children needing support for bullying of any kind was up 8 per cent between 2012 and 2013, according to ChildLine.

The charity's report found that the majority of the racist bullying affecting children was happening at school and many of those calling for counseling say teachers ignore the situation or make it worse with clumsy interventions. According to ChildLine, several young people who had the courage to tell a teacher then found that nothing happened or that they were given advice to simply ignore the bullies, which they found unhelpful and ineffective. Others were reluctant to speak out, fearing that the situation would become worse. Some actions taken by the school made things worse, some children said. For example, racist bullying being discussed in assembly simply advertised it and led to increased abusive behavior. This kind of bullying seems to be happening much more at school and on the way to school than on social media. While girls are ordinarily more likely to approach ChildLine about bullying, more boys get in touch about racist abuse. Of the calls and online counseling sessions, 52 per cent involved boys, 32 per cent girls and 16 per cent were gender unknown. The ChildLine report also found there was a dramatic rise in those seeking help with online abuse, with counseling for cyber bullying up 87 per cent in a year. The charity also reported a 41 per cent increase in contacts about selfharm and a 33 per cent increase in young people feeling suicidal. 
Students, both those who have recently moved from one country to another and those who were born in the country where they're living, but whose parents immigrated, report being frequently bullied by their peers. Interestingly, children who were born in a different country than where they live are also more likely than other students to bully, and sometimes form groups (such as gangs) that bully others. Pain from the experience of immigration, and from being bullied, could lead students to believe that there is a need to protect oneself or one's group rather than put up with being bullied - sometimes resulting in a decision to bully others. Children who feel like outcasts based on their heritage often feel hurt and angry, which could lead to behavioral problems down the line- and they need advocates for their protection and well-being. Taking a stand to eliminate hatebased bullying can have a positive impact on not only these students, but also on the levels of acceptance of students in general.

The CERIS Report study (Pepler et al., 2006) confirm the experience of ethnicallybased bullying among elementary and high school students. Seventeen percent of the students in this study had experienced ethnic victimization. Elementary students from minority ethnic groups were more likely to experience ethnic victimization than students from the majority group. The pattern in high school was similar but did not reach significance. A similar pattern was evident for immigration status: High school students not born in Canada reported more ethnically based victimization than those born in Canada. The trend for elementary students was similar but not significant. These data indicate that we should be concerned about the reception of minority and immigrant students in schools, as they may be harassed and excluded by other students for their differences, although in elementary school, there were not differences between the minority and majority students. In response to the question asking whether they had been bullied by a student from another ethnic group because of their ethnicity, $17 \%$ of all elementary students and $17 \%$ of all high school students reported that they had experienced ethnic victimization. Chi-square analyses indicated that elementary students from a minority group were significantly more likely to report ethnic victimization than those from the majority group. Although the rate for minority high school students was also higher than that for majority high school students, the difference did not reach significance.

According to Spriggs et al. (2007), bullying perpetration and victimization prevalence differed significantly by race/ethnicity, with a lower prevalence of victimization reported by black adolescents than whites and Hispanic adolescents. For white students, perceived family, peer and school relations were all associated with bullying involvement, but in different ways for bullies, victims and bully-victims-relative risk ratios and $95 \%$ confidence intervals. Bullies and victims were less likely than their noninvolved peers to live with both biological parents, and more likely to report low parent involvement in school; only bullies were more likely to report difficulty in communicating with parents. Bullies experienced less social isolation, whereas victims experienced more. Bullies, victims, and bully-victims all reported worse classmate relations, poorer academic performance, and less feelings of security at school than noninvolved counterparts. Fewer family, peer and school factors were related to bullying involvement for black than for white students, 
though some similar patterns emerged. Bully-victims were the only bullying-involved group who reported significantly lower parent school involvement than noninvolved peers, although both victims and bullies reported more difficult parent communication. Similar to their white counterparts, black bullies were less likely and victims more likely to be socially isolated; however only bullies and bully-victims reported significantly poorer classmate relations. School factors were largely unrelated to bullying behaviors for black students, with the exception of bullies' lower school satisfaction. Like black students, fewer family, peer and school factors differentiated bullying-involved from not involved youth for Hispanic compared with white students. The only family factor related to bullying was parental communication: victims and bully-victims reported more difficulty communicating with parents. As with white and black adolescents, bullies were less isolated and victims were more isolated; however, only victims and bullies reported worse classmate relations. Below average academic performance was associated with all three types of bullying involvement for Hispanic students, though dissatisfaction with school was associated only with bullying perpetration.

McKenney et al. (2006), find preliminary evidence that immigrant youth were at a higher risk for ethnic victimization, more specifically, youth who were born in Canada but whose parents were born outside of the country reported the highest rate of ethnic victimization, one explanation for this is that first generation youth may experience the greatest conflict between retaining the original cultural identities of their families and adopting and identity that is more consistent with the Canadian peer culture in which they are embedded. In the study of Kosciw J. et al., 2012, hearing racist remarks, such as "spic" or "nigger," in school was not uncommon, more than a third (41.6\%) reported hearing racist remarks from other students often or frequently in school. Over one fifth $(22.7 \%)$ of students reported that these types of remarks were made by most of their peers. In addition, almost a third (31.1\%) of students reported hearing racist remarks from faculty or other school personnel while in school.

\section{Measurements}

Study 1 was based on a cross-sectional sample group of 603 pupils in Compulsory Secondary Education in Spain (Navarra). The final unit of the sample was a class chosen at random from among the schools selected. The questionnaire used was basically the Olweus (1993) model. The survey was performed in May, to be able to take into account the events of the school year. Both the research objectives and the adequate completion of the questionnaire were explained in detail by the research team. School representatives were not allowed to be present in the classroom while the questionnaires were being completed, to ensure anonymity No personal identification whatsoever was required. The nominal variables were transformed into dummy variables in the case of gender ( 1 for males and 0 for females), of school type ( 1 for state schools and 0 for private) and of exposure to violence i.e. "Do you remember witnessing a violent act on TV, in the press or at school?" ( 1 for yes and 0 for 
not). Social class was proxied/approximated by using various neighborhood characteristics (e.g. households below the poverty line, unemployed persons and immigrants), as proposed by Sampson $(1997,1999)$. In addition, house prices were taken into account, and all the above were used to divide interviewees to form three social classes or economic status groups: low, middle and upper. Family and school climate were indicated using a classic four-point scale ( 1 = very good, 4 = very bad). The different measurements of bullying and TV watching frequency were also obtained using a 1-4 scale. Study 2 was based on a cross-sectional sample group of 732 pupils in Compulsory Secondary Education in Spain (Navarra) in same conditions incorporating race and ethnic groups.

Furthermore, an attempt was made to ensure that the schools selected reflected in some way social classes and neighborhoods, in order to test two hypotheses of residential theories. The first one is that violence may be a cause of the social disorganization occurring in some areas of the city, as a result of the decrease in the social control exercised by neighbors and various collectives, who act as a restraint upon the performance of criminal acts. Although, in principal, this theory is aimed at measuring the influence of the immigrant population, whether national or foreign, the low level of immigration in certain ages of Navarre prevented it being tested- nevertheless, it remains valid in order to obtain a measurement of the zones. The second hypothesis is that differences exist between rural and urban areas. Another theory considered to be important in/relevant to the interpretational framework of the study was that known as differential association according to which violent socialization is not produced solely on the basis of geographical area, but also on the basis of membership of specific collectives.

\section{AnALYTIC VARIABLE CONSTRUCTION}

Two main data collection instruments were used with respect to young people's experience of bullying: a self report questionnaire and semi-structured interviews with young people targeted by the intervention project and, in some cases, their professor. The questionnaires investigated the experience of being bullied, of bullying and of seeing others bullied; the reporting of bullying and being found out; and young people's feelings of safety in school. Truancy, school exclusion and offending behavior were also explored. The rationale for using a self-report study is briefly explained and the analyzed results of the questionnaire are reported. The paper is structured around the statistical data derived from the questionnaires. I make tentative interpretations of these data and illustrate them by drawing on the interview data.

Bullying definition was explained to students as being the bullying when a student or students hurt someone. For example when students say mean and hurtful things; ignore or exclude students; hit, kick, push, shove others around, spread rumors about someone, or send mean notes, try to make other students dislike someone; or use a computer or cell phone to do these things, etc. Bullying is when these things happen repeatedly, and it is difficult for the student being bullied to defend against it or make the other person stop. 
But we don't call it bullying when the teasing is done in a friendly and playful way and it does not bother the other person. Also, it is not bullying when two students of about equal strength or power argue or fight. Please use this definition to answer the next question. Instructions were: Don't put your name on this booklet. No one will know how you have answered these questions. But it is important that you answer carefully and how you really feel. Sometimes it is hard to decide what to answer. Then just answer how you think it is. If you have questions, raise your hand.

Table 1.

Variables content

\begin{tabular}{|c|c|}
\hline Individual/ Collective Bullying & $\begin{array}{l}\text { How often have you taken part in bullying another student(s) at school in } \\
\text { the past couple of months? } \\
\text { I have not bullied another student (s) at school in the past couple of months. } \\
\text { It has only happened once or twice } \\
2 \text { or } 3 \text { times a month } \\
\text { About once a week }\end{array}$ \\
\hline Victimization Bullying & $\begin{array}{l}\text { How often have you been bullied at school in the past couple of months?: } \\
\text { I haven't been bullied at school in the past couple of months } \\
\text { It has only happened once or twice } \\
2 \text { or } 3 \text { times a month } \\
\text { About once a week }\end{array}$ \\
\hline Observed Bullying & $\begin{array}{l}\text { How often do other students try to put a stop to it when a student is being } \\
\text { bullied at school? } \\
\text { almost never } \\
\text { sometimes } \\
\text { often } \\
\text { almost always }\end{array}$ \\
\hline Climate in school & $\begin{array}{l}\text { How do you like school? } \\
\text { I dislike school very much } \\
\text { I dislike school } \\
\text { I neither like nor dislike school } \\
\text { I like school } \\
\text { I like school very much }\end{array}$ \\
\hline Social capital & $\begin{array}{l}\text { How many good friends do you have in your class(es) } \\
\text { none } \\
\text { I have } 1 \text { good friend in my class(es) } \\
\text { I have } 2 \text { or } 3 \text { good friends } \\
\text { I have } 4 \text { or } 5 \text { good friends } \\
\text { I have } 6 \text { or more good friends in my class(es) }\end{array}$ \\
\hline Family climate & $\begin{array}{l}\text { How do you like family } \\
\text { I dislike family very much } \\
\text { I dislike family } \\
\text { I like family } \\
\text { I like family very much }\end{array}$ \\
\hline Nationality/Race/Immigration & $\begin{array}{l}\text { What is your nationality } \\
\text { Spain } \\
\text { Not Spain (Ecuador, Peru, Bolivia, Morocco, Colombia, Dominican Republic, } \\
\text { Bulgaria, Romania, Argentina, Cuba, Lithuania, Poland ..) }\end{array}$ \\
\hline
\end{tabular}




\section{RESULTS}

Table 2.

Descriptive statistics. Study 1 (2002) and Study 2 (2010)

\begin{tabular}{l|c|c|c|c|c|c|c|c|c|c}
\hline & \multicolumn{2}{|c|}{ Number } & \multicolumn{2}{c|}{ Means } & \multicolumn{2}{c|}{ Standard deviations } & \multicolumn{2}{c|}{ Mínimum } & \multicolumn{2}{c}{ Máximum } \\
\hline & Study 1 & Study 2 & Study 1 & Study 2 & Study 1 & Study 2 & Study 1 & Study 2 & Study 1 & Study 2 \\
\hline Class & 603 & 732 & 2,129 & 2,32 & 0,7514 & 0,76 & 1 & 1 & 3 & 4 \\
Gender & 603 & 732 & 0,52 & 0,52 & 0,500 & 0,500 & 0 & 0 & 1 & 1 \\
Age & 603 & 732 & 14,98 & 14,75 & 0,969 & 1,322 & 12 & 12 & 19 & 19 \\
Scool type (private,/public) & 603 & 732 & 0,54 & 0,539 & 0,499 & 0,498 & 0 & 0 & 1 & 1 \\
Climate in family & 603 & 732 & 1,35 & 1,27 & 0,568 & 0,499 & 1 & 1 & 4 & 4 \\
Climate in school & 603 & 732 & 2,00 & 1,72 & 0,750 & 0,648 & 1 & 1 & 4 & 4 \\
Victimization & 603 & - & 2,17 & - & 0,971 & - & 1 & - & 4 & - \\
External Bullying & 603 & 732 & 1,94 & 1,40 & 0,864 & 0,575 & 1 & 1 & 4 & 4 \\
Individual Bullying & 603 & 732 & 1,65 & 1,34 & 0,627 & 0,616 & 1 & 1 & 4 & 4 \\
Group Bullying & 603 & 732 & 1,47 & 1,30 & 0,720 & 0,655 & 1 & 1 & 4 & 4 \\
Friends & 603 & 732 & 1,47 & 2,39 & 0,650 & 1,140 & 1 & 1 & 4 & 5 \\
Exposure televisión & 603 & 732 & 1,85 & 1,49 & 0,618 & 0,799 & 1 & 1 & 4 & 4 \\
Exposure to violence & 603 & 732 & 1,11 & 1,66 & 0,319 & 0,770 & 1 & 1 & 2 & 3 \\
Immigrant & - & 732 & - & 2,34 & - & 3,456 & - & 1 & - & 24 \\
\hline
\end{tabular}

The data available on schoolyard bullying in Spain for adolescents of between 12 and 18 years of age in Compulsory Secondary Education show that between 3 and $5 \%$ of students are victims of severe bullying whereas between 15 and $20 \%$ suffer moderate bullying. These rates are higher than those of other European countries, particularly for moderate bullying. The Spanish education system receives a poor rating both in the PISA report and in international mathematics testing. There may be a relation between both realities as one of the most notable effects of bullying victimization is school drop-out and constant disruption in the classroom making effective teaching impossible. This acquires added importance in the light of the relationship which has been established between a country's education ratio and its level of economic productivity or between education and human development. Many studies have done their utmost to detect the potential number of students affected by such violence, and likewise its principal characteristics. However, such research has focused on the personal characteristics of the violent person or of the victim, or on the norms governing group relationships, or even peer groups; there are notably fewer studies of the social/environmental circumstances which influence bullying in school. Within the field of Sociology, the phenomenon of bullying has virtually gone unnoticed, although similar typologies have been used in seminal delinquency theories. 
Individual harassment decreased from the $3.8 \%$ of students by whom it was carried out "almost every day" in Study 1 to $1.0 \%$ by whom it was carried out "almost every day" in Study 2. In this epigraph, the response to "I don't harass anybody" increased from $58.5 \%$ in Study 1 to $66 \%$ in Study 2. The same tendency can be observed with group harassment which descended from $2.6 \%$ that participated "almost every day" in Study 1 to $0.3 \%$ that participated "almost every day" in Study 2. In this epigraph, the response to "I don't harass anybody" increased from 58.5\% in Study one $175.5 \%$ in Study 2. A clear improvement in the situation of bullying in school can be observed which, on the other hand, is reflected in the vast majority of the longitudinal studies carried out in Spain. As regards victimization, it should be noted that while the question was different in Study one: "Have any of your classmates suffered rejection"? to the one in Study two: "Have you felt rejected by your classmates since the start of the school year"?, the responses were significant, in that in Study 1, 81,2\% answered "almost every day", "more than four times" or "at some point" as opposed to the $6.1 \%$ who answered "yes" in Study 2, which would point to an abysmal variation after two years.

Table 3.

Correlations matrix. Study 1 (2002) and Study 2 (2010, in brackets).

\begin{tabular}{|c|c|c|c|c|c|c|c|c|c|c|c|}
\hline & Clase & Gen & Age & Schoo & Clim & Clim & Exter & Indivi & Group & Friend & Mass \\
\hline 1. Class & - & & & & & & & & & & \\
\hline 2. Gender & \begin{tabular}{|c|}
, 024 \\
$\left(.088^{\star}\right)$ \\
\end{tabular} & - & & & & & & & & & \\
\hline 3. Age & $\begin{array}{l}-214^{* *} \\
\left(.232^{\star *}\right)\end{array}$ & $\begin{array}{l}125^{\star \star} \\
(.007) \\
\end{array}$ & - & & & & & & & & \\
\hline 4. School & $\begin{array}{c}-, 049 \\
\left(.232^{* *}\right)\end{array}$ & $\begin{array}{l}-, 089^{*} \\
(.030) \\
\end{array}$ & \begin{tabular}{|l|}
, 033 \\
$(.420)$ \\
\end{tabular} & - & & & & & & & \\
\hline 5. Climate in family & \begin{tabular}{|l|}
, $087^{*}$ \\
$(.012)$
\end{tabular} & $\begin{array}{c}-, 024 \\
(.012)\end{array}$ & $\begin{array}{c}0.040 \\
(-.017)\end{array}$ & \begin{tabular}{|l|}
, 067 \\
$(.103)$
\end{tabular} & - & & & & & & \\
\hline 6. Climate in school & $\begin{array}{c}, 061 \\
(.014) \\
\end{array}$ & $\begin{array}{l}1117^{\star \star} \\
(-.014)\end{array}$ & $\begin{array}{l}, 085^{*} \\
(.003)\end{array}$ & $\begin{array}{l}, 056 \\
(.170) \\
\end{array}$ & \begin{tabular}{|l|}
, $218^{* *}$ \\
$(.000)$
\end{tabular} & - & & & & & \\
\hline 7. External Bullying & $\begin{array}{c}-134^{* *} \\
(.001)\end{array}$ & $\begin{array}{c}.018 \\
(.657)\end{array}$ & \begin{tabular}{|l|}
-019 \\
$(641)$
\end{tabular} & $\begin{array}{l}.143^{\star \star} \\
(.000)\end{array}$ & $\begin{array}{l}.098^{*} \\
(.016)\end{array}$ & $\begin{array}{l}.099^{*} \\
(.015)\end{array}$ & - & & & & \\
\hline 8. Individua Bullyingl & $\begin{array}{l}-.313^{\star *} \\
\left(.310^{* *}\right)\end{array}$ & $\begin{array}{c}.084^{*} \\
\left(.139^{* \star}\right)\end{array}$ & $\begin{array}{l}.039 \\
(.059)\end{array}$ & $\begin{array}{l}.025 \\
(.547)\end{array}$ & $\begin{array}{l}-, 013 \\
(.754) \\
\end{array}$ & $\begin{array}{c}.043 \\
\left(.083^{*}\right)\end{array}$ & \begin{tabular}{|l}
, $275^{* \star}$ \\
$(.000)$
\end{tabular} & - & & & \\
\hline 9. Group Bullying & $\begin{array}{l}, 252^{\star *} \\
\left(.587^{\star}\right)\end{array}$ & \begin{tabular}{|c|}
,- 008 \\
$(.047)$
\end{tabular} & $\begin{array}{c}-, 078 \\
\left(.088^{*}\right)\end{array}$ & $\begin{array}{l}, 130^{\star \star} \\
(.001)\end{array}$ & \begin{tabular}{|l|}
.044 \\
$(.277)$ \\
\end{tabular} & \begin{tabular}{|l|}
, 077 \\
$(.003)$
\end{tabular} & \begin{tabular}{|l|}
, 042 \\
$(.299)$ \\
\end{tabular} & $\begin{array}{c}, 042 \\
\left(.556^{\star \star}\right)\end{array}$ & - & & \\
\hline 10. Frinds & \begin{tabular}{|l|}
,$- 117^{*}$ \\
$(.004)$
\end{tabular} & $\begin{array}{c}-, 021 \\
(.608) \\
\end{array}$ & \begin{tabular}{|l|}
, 005 \\
$(.893)$ \\
\end{tabular} & \begin{tabular}{|l|}
, 010 \\
$(.803)$ \\
\end{tabular} & \begin{tabular}{|l|}
, $087^{\star}$ \\
$(.032)$ \\
\end{tabular} & $\begin{array}{l}, 105^{\star *} \\
(.010)\end{array}$ & $\begin{array}{l}169^{* *} \\
(000)\end{array}$ & $\begin{array}{l}, 320^{* *} \\
(.000)\end{array}$ & \begin{tabular}{|l|}
-049 \\
$(.233)$ \\
\end{tabular} & - & \\
\hline 11. Mass media & \begin{tabular}{|l}
, $081^{*}$ \\
$(.043)$
\end{tabular} & $\begin{array}{c}, 017 \\
(.674) \\
\end{array}$ & \begin{tabular}{|c|}
,-- 002 \\
$(.355)$ \\
\end{tabular} & $\begin{array}{l}, 114^{* *} \\
(.005)\end{array}$ & \begin{tabular}{|l|}
, $116^{* *}$ \\
$(.004)$
\end{tabular} & $\begin{array}{l}.098^{*} \\
(.016)\end{array}$ & $\begin{array}{l}, 021 \\
(.609) \\
\end{array}$ & $\begin{array}{c}, 029 \\
(.478) \\
\end{array}$ & \begin{tabular}{|c|}
, 055 \\
$(.895)$ \\
\end{tabular} & $\begin{array}{l}--, 005 \\
(.929) \\
\end{array}$ & - \\
\hline 12. Esposure to violence & \begin{tabular}{|c|}
, 014 \\
$(.224)$
\end{tabular} & $\begin{array}{l}064 \\
(.114) \\
\end{array}$ & \begin{tabular}{|c|}
,- 053 \\
$(.197)$ \\
\end{tabular} & $\begin{array}{l}-, 103^{*} \\
(.012)\end{array}$ & \begin{tabular}{|l|}
,$- 096^{*}$ \\
$(.018)$
\end{tabular} & \begin{tabular}{|l|}
, 039 \\
$(.335)$
\end{tabular} & \begin{tabular}{|l|}
,- 020 \\
$(618)$
\end{tabular} & \begin{tabular}{|c|}
,- 021 \\
$(.614)$
\end{tabular} & \begin{tabular}{|l|}
,-021 \\
$(.614)$ \\
\end{tabular} & $\begin{array}{c}--, 012 \\
(.766)\end{array}$ & \begin{tabular}{|l|}
, 061 \\
$(.137)$
\end{tabular} \\
\hline
\end{tabular}

${ }^{* *} \rho<0,01,{ }^{*} \rho<0,05$. 


\section{Conclusions}

Agree Bronfrenbrenner's theory, the bio-ecological variables that come into play in bullying could be: age, gender, family, school, the mass media and forms of entertainment, and community. All of these are potential risk factors, but they can also serve as mechanisms of protection and resilience. Age and gender are universal and timeless variables that have not been subject to change in recent years. An exception might be the culture of masculinity, but in general terms, it can be said that their atavic effects have remained immutable and inalterable. The risk of bullying intensifies when these two variables are present. Another key factor in determining risk is the role of the mass media and the forms of leisure time entertainment. The long and short term effects of the latter have multiplied in recent years with the invasion of violent video games and the massive extension of the Internet. The use of these means of entertainment has changed dramatically. While in the past, they tended to be more group orientated, open and easier to supervise, they has now become more individual, closed and difficult to control, when accessed on mobile phones, iPads and the Internet.

Directly following the above mentioned variables come the others, which also carry with them the potential to serve as factors of risk or protection. The family has undergone significant changes since the 1950's when American sociologists warned about the risk involved with respect to the supervision of children as mothers joined the work force, temporarily leaving the home. The family can be potentially a high risk variable when it suffers economic difficulties or when it becomes structurally fragile and cannot be sufficiently involved in the socialization of the children, in the supervision of the children's free time activities and in collaboration with the school. A similar analysis can be made of schools which have also dramatically transformed, having taken on the socializing function that previously corresponded to the family. The time children spend at school has doubled if we include the extra curriculum activities they engage in, normally to accommodate parents' work schedules. While the risk of bullying increases in this scenario, recent judicial sentences given to schools for negligence, has led to a rise in the number of courses given to children, focused on drastically reducing the incidences of bullying. This means that schools have incorporated the protection/ resilience factor. This follows Popper's thesis that the function of institutions is to have devils behaving like angels. And, finally, the community, which has the potential to be the best protection/ resilience factor for both the adolescent population that resides there and for the school that is situated there, provided it is efficiently organized, provides social capital, and creates a climate where agreement can be reached among its members in order to acquire resources.

The results of the Study 1 (Hernández T., 2000, Hernández T., 2009) tend to corroborate earlier theories, since they demonstrate a higher ratio of violence in schools located in the area of center and the surrounding area in comparison to the other three areas 
of South, Southeast; North, since Pamplona registers twice the percentage of witness records of violent acts. This may be the result of it being a city of 200,000 inhabitants i.e. it is more urbanized, more crowded and has larger districts than the other, much smaller towns. The general conclusion in this regard is that the greater the size of the municipality, the higher is the incidence of bullying in schools. Similarly, comparing the two most urbanized areas of Pamplona and its surroundings and South, South-east and North, the figures are also higher, and thus we are able to confirm the initial hypothesis. However, caution must be exercised on this point, since the sampling errors of the last two geographical areas do not permit a balanced comparison to be made. The results of Study 2 tend to corroborate the previous relationship and the emergence of a new one associated solely and exclusively to bullying within the social class/school and which could determine that the school which adopts appropriate measures provides an important protective factor, but if it does not adopt such measures, it represents a clear risk factor.

The evolution of the data reflects a clear decrease in adolescent bullying in Navarre, from 2002 to 2010, which is consistent with the greater part of the longitudinal studies carried out in Spain. It must be said that since the study of the year 2002, bullying has been a concern among political and institutional power once the media started to focus on this problem. In Navarre, as in almost all Spanish autonomous communities, attention was given to the issue which resulted in the setting up of numerous awareness raising campaigns, summer courses and programs of support for victims, including a telephone helpline. The matter was addressed by the Ombudsman of Navarra, following the guidelines set by the original study of the Spanish Ombudsman, and a session was held on the subject in the Parliament of Navarre. In 2010, the bivariate correlations clearly point to a relationship between bullying and the school. At that time there were 2 or 3 schools that still had not started awareness raising programs. To conclude conclusion it must be said that although the rest of the variables have increased their negative influence, the variable "community" (political power capable of carrying out campaigns and supervision of schools) and school have become the key variables of protection/resilience.

\section{References}

Anderson, C. A., Gentile, D. A. and Dill, K. E. 2012. "Prosocial, anti- social, and other effects of recreational video games" Pp. 249-272 in Handbook of children and the media, edited by D.G. Oaks G. Singer and J. L. Singer., California: Thousand.

Austin SB, Ziyadeh NJ, Corliss HL, Haines J, Rockett HR, Wypij D, Field AE. Sexual orientation disparities in weight status in adolescence: Findings from a prospective study. Obesity. 2009;17(9): 1776-1782.

Baldry, A. and Farrington, D. 2005. "Protective factors as moderators of risk factors in adolescent bullying". Social Psychology of Education 8: 263-284.

Boxer, P., Huesmann, L. R., Bushman, B. J., O'Brien, M. and Moceri, D. 2008. "The role of violent media preference in cumulative developmental risk for violence and general aggression". Journal of Youth and Adolescence 38: 417-428. 
Bronfenbrenner U. 2005. Making human beings human: Bioecological perspectives on human development. Thousand Oaks, CA: Sage Publications.

Bronfenbrenner U. and Ceci S.J. 1994. "Nature-nurture reconceptualized in developmental perspective: a bioecological model". Psychological Review 101 4: 568-586.

Bronte-Tinkew, J., Horowitz, A. and Scott, M. E. 2009. "Fathering with multiple partners: Links to children's well-being in early childhood". Journal of Marriage and Family 71: 608-631.

Brophy-Herb, H. E., Martoccio, T., Hillaker, B., Stansbury, K. E., Harewood, T., Senehi, N. and Fitzgerald H. 2013. "Profiles of low- income maternal well-being and family climate: Relations to toddler boys' and girls' bahaviors. Family Relations 62: 326-340.

Bushman, B. J. and Huesmann, L. R. 2012. "Effects of violent media on aggression". Pp. 231-248 in Handbook of children and the media 2nd ed. By D. G. Singer and J. L. Singer. California: Thousand Oaks.

Carney, J., Jacob, C. J. and Hazler, R. J. 2011. Exposure to school bullying and the social capital of sixth-grade students. Journal of Humanistic Counseling, 50: 238-253.

ChildLine 2013. "Can I tell you something? What's affecting children in 2013." www.mspaa.uk.

Cohen, J., McCabe, L., Michelli, N. M., and Pickeral, T. 2009. "School climate: Research, policy, practice, and teacher education". Teachers College Record 111: 180-213.

Coker TR, Austin SB, Schuster MA. 2010. The health and health care of lesbian, gay, and bisexual adolescents. Annual Review of Public Health. 31:457-477.

Donnerstein, E. 2011. "The media and aggression: From TV to the Internet" Pp. 267-284 in The psychology of social conflict and aggression, edited by J. P. Forgas, and A. W. Kruglanski. New York: Psychology Press.

Espelage, D. L. 2011. "Bullying \& the lesbian, gay, bisexual,transgender, questioning (LGBTQ) community." White Paper for the White House Conference on Bullying Prevention, Washington, D.C.

Farhat T., lannotti R., and D. Simons-Morton 2010. "Overweight, Obesity, Youth, and Health-Risk Behaviors." American Journal of Preventive Medicine 38: 258-267.

Gentile, D. A. and Sesma, A. 2003. "Developmental approaches to under- standing media effects on individuals". Pp. 19-38 in Media violence and children: A complete guide for parents and profession als, edited by D. A. Gentile. Westport, CT: Praeger.

Halpern-Meekin, S., Manning, W. D., Giordano, P. C. and Longmore, M. A. 2013. "Relationship churning, physical violence, and verbal abuse in young adult relationships". Journal of Marriage and Family 75: 2-12.

Hernández de Frutos T. 2000. "La violencia bullying en las relaciones de género entre escolares de Navarra". Revista Internacional de Sociología 10: 1-31.

Hernández de Frutos T. 2009. "A socio-ecological perspective on bullying. A new síntesis". Revista Internacional de Sociología 67 (3): 631-654.

Himmelstein, K. E. W., and Bruckner, H. 2011. Criminal-justice and school sanctions against non-heterosexual youth: A national longitudinal study. Pediatrics, 127(1): 49-57.

Institute of Medicine 2011. The Health of Lesbian, Gay, Bisexual, and Transgender People: Building a Foundation for Better Understanding. Washington, DC: The National Academies Press. 
Instituto de Evaluación 2006. Sistema estatal de indicadores de la educación. Madrid. Ministerio de Educación y Ciencia. Madrid.

Jansen, P. W., Verlinden, M., Berkel, A. D., Mieloo, C., Van der Ende, J., Veenstra, R., Verhulst, F. C., Jansen, W. and Tiemeier, H. 2012. "Prevalence of bullying and victimization among children in early elementary school: Do family and school neighborhood socioeconomic status matter?"p.BMC Public Health 12:494.

Janssen I., Craig W. , Boyce W., and W. Pickett 2004. "Associations Between Overweight and Obesity With Bullying Behaviors in School-Aged Children." Pediatric 113(5):1187-1194.

Jencks, C. and Mayer, S. 1990. "The social consequences of growing up in a poor neighbourhood". Pp. 111-186 in Inner-city poverty in the United States, edited by L. E. Lynn, and M. F. H. McGeary. Washington DC: National Academy Press.

Jenson J. and Fraser M. 2011. "A Risk and Resilience Framework for Child, Youth, and Family Policy". Pp. 1-18 in Social Policy for Children and Families. A Risk and Resilience Perspective, edited by J. Jenson and M. Fraser. New York: Sage.

Kann L., Olsen E., McManus T, Kinchen S, Chyen D, Harris WA, Wechsler H. 2011. Sexualidentity, sex of sexual contacts, and health-risk behaviors among students in grades 9-12: Youth risk behavior surveillance United States, 2001-2009 MMWR (Vol. 60). Atlanta, GA.

Kosciw JG, Greytak EA, Diaz EM, Bartkiewicz MJ. 2011. The 2009 National School Climate Survey: The Experiences of Lesbian, Gay, Bisexual and Transgender Youth in Our Nation's Schools. New York: Gay, Lesbian Straight Education Network.

Krahé, B. 2013. "Violent video games and aggression". Pp. 352-373 in The Oxford handbook of media psychology edited by K. Dill. Oxford: Oxford University Press.

LeBlanc, L., Swisher, R., Vitaro, F. and Tremblay, R. E. 2007. "School social climate and teachers' perceptions of classroom behavior problems: A 10-year longitudinal and multilevel study". Social Psychology of Education 10: 429-442.

Leventhal, T. and Brooks-Gunn, J. 2000. "The neighborhoods they live in: The effects of neighborhood residence on child and adolescent outcomes". Psychological Bulletin 126: 309-337.

Ludwing, J., Duncan, G. J., Gennetian, L. A., Katz, L. F., Kessier, R. C., Kling, J. R. and Sanbonmatsu, L. 2012. "Neighborhood effects on the long-term well-being of low-income adults". Science 337: 1505-1510.

McKenney K., Pepler D., Craig W., Connolly J. 2006. "Peer victimization and psychosocial adjustment: the experiences of Canadian immigrant youth." Electronic Journal of Research in Educational Psychology 9: 239-264.

Menasco, M. A. 2012. "Family financial stress and adolescent sub- stance use. An examination of structural and psycholosocial factors". Economic Stress and the Family 6: 285-315.

O'Mallet E., kann L., Vivolo-kantor A., Kinchen S. and Mcmanus T. 2014. School violence and bullying among sexual minoritt school students, 2009-2011. Journal of Adolescent Health. Forthcoming.

Olsen K., Manus T, Kinchen S, Chyen D, Harris WA, Wechsler H. 2011. "Sexual identity, sex of sexual contacts, and health-risk behaviors among students in grades 9-12 youth risk behavior surveillance, selected sites", United States, 2001-2009. Centers for Disease Control and Prevention (CDC). 
Pepler, D., Connolly, J., and Craig, W. 1999. Bullying and harassment: Experiences of immigrant and minority youth. CERIS Report.

Pernille, D., Mogens, T. D., Rikke, L. and Bjørn, E. H. 2009. "Is bullying equally harmful for rich and poor children? A study of bullying and depression from age 15 to 27". European Journal of Public Health 19: 464-469.

Peters, B. and Ehrenberg, M. F. 2008. "The influence of parental separation and divorce on father-child relationships". Journal of Divorce and Remarriage 49: 78-109.

Peterson, and Bush 2013. Handbook of marriage and the family. New York: Springer.

Poteat VP, Sinclair KO, DiGiovanni CD, Koenig BW, Russell ST. 2013. "Gaystraight alliances are associated with student health: A multischool comparison of LGBTQ and heterosexual youth." Journal of Research on Adolescence 23: 319-330.

Poteat, V. P., Mereish, E. H., Giovanni, C. D., and B. W. Koenig 2011. "The effects of general and homophobic victimization on adolescents' psychosocial and educational concerns: The Importance of intersecting identities and parent support." Journal of Counseling Psychology 58 (4): 597-609.

Puhl R. and K. King 2014. "Weight discrimination and bullying. Best Practice \& Research Clinical" Endocrinology \& Metabolism 28: 117-127.

Raskauskas, J., Gregory, J., Harvey, S. T., Rifshana, F. and Evans, I. M. 2010. "Bullying among primary school children in New Zealand: Relationships with prosocial behaviour and classroom climate". Educational Research 52: 1-13.

Resnick M.D. and Taliaferro L. A. 2011. Resilience. Encyclopedia of Adolescence, Vol. 1. University of Minnesota: Elsevier Inc.

Robinson, J. and Espelage, D. 2011. Inequities in educational and psychological outcomes between LGBTQ and straight students in middle and high school. Educational Researcher, 40(7): 315-330.

Rutter, M. 2006. "Implications of resilience concepts for scientific understanding". Annals of New York Academic of Sciences 1094:1-12.

Scherr T. and Larson J. 2010. "Bullying dynamics associated with race, ethnicity, and inmigration status" Pp. 223- 234 in Handbook of bullying in schools edited by S. Jimerson, S. Swearer and D. Espelage D. New York. Routledge.

Shields J., Whitaker, K., Jill Glassman, J., Heather M. Franks, M.A., and Howard K., 2012. "Impact of Victimization on Risk of Suicide Among Lesbian, Gay, and Bisexual High School Students in San Francisco." Journal of Adolescent Health 50: 418-420.

Spriggs A., lannotti R., Nansel T., Haynie D. 2007. "Adolescent bullying involvement and perceived family, peer and school relations: commonalities and differences across race/ethnicity." Journal of Adolescente Health 41: 283-293.

Ungar M. 2011. "Community resilience for youth and families: Facilitative physical and social capital in contexts of adversity". Children and Youth Services Review 33: 742-1748.

Virtanem, M., Kivimäki, M., Elovainio, M., Linna, A., Pentti, J. and Vahtera, J. 2007. "Neighborhood socioeconomic status, health and working conditions of school teachers". Journal of Epidemiology and Community Health 61: 326-330. 
Waldfogel, J., Craigie, T. H. and Brooks-Gunn, J. 2010. "Fragile families and child wellbeing". Future Child 20: 87-112.

Weiss, J. W., Mouttapa, M., Cen, S., Johnson, C. A., and Unger, J. 2011. "Longitudinal effects of hostility, depression, and bullying on adolescent smoking initiation." Journal of Adolescent Health 38: 591-596.

Teodoro Hernández de Frutos is Ph.D. in Sociology from the Universidad Complutense of Madrid (1990). Lecturer in Universidad Pública de Navarra (1991) and Professor Aneca in Universidad Pública of Navarra (2010). Visisting Researcher in Harvard, Oxford, Cambridge and College of Dublin. Current research includes the study of variables affecting bullying (Teodoro Hernández de Frutos, 2000, 2002, 2009, 2013 and Casares, 2010) and labour relations and social cohesion in Spain (Teodoro Hernández de Frutos, 2003, 2006, 2007, 2012).

Nuria del Olmo Vicén is PhD in Social and Political Sciences from the European University Institute of Florence (1998). Lecturer in the university of Zaragoza (2006) and Visisting Researcher in Mediterranean international studies (Autonomous University of Madrid) and workshop and patronage South-North Solidarity and culture (University of Valencia). Current research includes the study of bullying, migration and identity construction processes.

RECEIVED: 07 May 2013

ACCEPTED: 26 February 2014

PUBLISHED ONLINE: 29 July 2014 